\title{
Rethinking the British World
}

\section{Tamson Pietsch}

\begin{abstract}
This article rethinks the concept of the "British World" by paying close attention to the voices of those who attended the 1903 Allied Colonial Universities Conference. They identified not one, but three different kinds of British world space. Mapped, respectively, by ideas and emotions, by networks and exchange, and by the specific sites of empire, this article suggests that, in the light of criticisms the British World concept has faced, and in the context of recent scholarship on the social and material production of space, this tripartite approach might offer a useful framework for British and imperial historians interested in the history of the global.
\end{abstract}

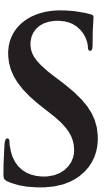

tanding in the lecture theater at Burlington House in July 1903 for the first Allied Colonial Universities Conference, the Liberal member of Parliament and historian James Bryce announced that the meeting was designed to facilitate cooperation between "the universities of the British world." In doing so, he articulated a concept that since the late 1990s has animated historians seeking to recover the connections linking the countries "set going" by migration from Britain. Pursued mostly by British imperial historians and scholars from the former Dominions, this British World project flowered in the early 2000s, resulting in a series of conferences and publications. However, a decade after its inception, the movement reached something of an impasse, beset by definitional imprecision and criticized for its inattention to questions of power. Nonetheless, in the last few years, a number of books have emerged that again invoke the concept, utilizing it as a way of explaining the origins and processes of globalization. The appearance of these works suggests that it is time to reevaluate the utility of the idea of the British World.

This article rethinks the concept of the British World by paying close attention to the voices of those who attended the 1903 Allied Colonial Universities Conference. At this meeting, the delegates identified not one, but rather three different kinds of British world space. Mapped, respectively, by ideas and emotions, by networks and exchange, and by the specific sites of empire, they pointed to the imagined, material, and local British worlds that reflected their lived experience of the globalizing connections of the period. This article argues that, in the context of recent scholarship on the

Tamson Pietsch is lecturer in imperial and colonial history at Brunel University, London. She would like to thank Jay Sexton, Matt Houlbrook, Rahul Rao, Jared van Duinen, and Ben Mountford, as well as the reviewers and editors for the Journal of British Studies, for their helpful comments on earlier versions of this piece.

${ }^{1}$ James Bryce, "Official Report of the Allied Colonial Universities Conference," Empire Review 6, no. 31 (August 1903): 73. 
social and material production of space, this tripartite approach might offer a useful framework for British and imperial historians interested in the history of the global.

\section{THE FLOWERING AND FLOUNDERING OF THE BRITISH WORLD PROJECT}

The idea of the British World emerged at the end of the 1990s, advanced by imperial historians and scholars from the former Dominions who wished to take up the history of the settler societies' connections with Britain. ${ }^{2}$ This, they argued, was a story that had been abandoned in the second part of the twentieth century. Influenced by feminism, postwar migration, decolonization, and social history, national historians had instead turned their attention to questions of domestic power and privilege, charting the demise of British sentiment as part of what was sometimes cast as "an inevitable process of national self-realisation." 3 The story of settler connection was, moreover, also one that British World historians claimed was being neglected by the "new imperial historians," who at the time were reframing the writing of imperial history in Britain. Influenced by developments within postcolonial theory, these scholars saw culture as a site of power and argued that constructions of race, gender, class, and sexuality had to be seen as "grammars of difference" that mutually shaped the lives and identities of both colonized and colonizer. ${ }^{4}$ Although the members of the group that organized the first British World conference in London in 1998 were attracted to the new imperial historians' call to see metropole and colony together within a single analytic frame, they criticized this scholarship for having "virtually nothing to say about the encounters millions of British migrants had with earlier generations of people who were curiously very much like themselves but also quite different."

Instead, these historians looked back to J. G. A. Pocock's call in 1973 to integrate into a "new British history" the then largely separate narratives being told about Scotland, Ireland, and England, on the one hand, and the equally separate stories being told about the Dominions, or "neo-Britains," on the other. ${ }^{6}$ Citing the writings of commentators such as J. R. Seeley, Charles Dilke, and J. A. Froude, the group pointed out that the British World was not only a concept that they had developed at the end of the twentieth century but also one that, in the form of discussion about Greater Britain or closer imperial union, was employed by scholars who lived and wrote in the nineteenth. The "expansion of Britain and the peopling and

\footnotetext{
${ }^{2}$ For an overview of the origins of the project, see Phillip A. Buckner, "Introduction: The British World," History of Intellectual Culture 4, no.1 (2004): 1-4.

${ }^{3}$ Stuart Ward, "Sentiment and Self-Interest: The Imperial Ideal in Anglo-Australian Commercial Culture," Australian Historical Studies 32, no. 116 (April 2001): 96.

${ }^{4}$ Catherine Hall and Sonya O. Rose, "Introduction: Being at Home with the Empire," in At Home with the Empire: Metropolitan Culture and the Imperial World, ed. Catherine Hall and Sonya O. Rose (New York, 2006), 19; Catherine Hall, "Culture and Identity in Imperial Britain," in The British Empire: Themes and Perspectives, ed. Sarah E. Stockwell (Malden, MA, 2007), 202.

${ }^{5}$ Carl Bridge and Kent Fedorowich, "Mapping the British World," in The British World: Diaspora, Culture and Identity, ed. Carl Bridge and Kent Fedorowich (London, 2003), 2.

${ }^{6}$ J. G. A. Pocock, The Discovery of Islands: Essays in British History (Cambridge, 2005), 22; Bridge and Fedorowich, "Mapping the British World," 6. See also J. G. A. Pocock, "Conclusion, Contingency, Identity, Sovereignty," in Uniting the Kingdom? The Making of British History, ed. Alexander Grant and Keith J. Stringer (London, 1995), 297.
} 
building of the trans-oceanic British world" was, argued Carl Bridge and Kent Fedorowich in the volume that emerged from the 1998 meeting, at the heart of the late nineteenth-century vision of the imperial enterprise. ${ }^{7}$

The mass migration of people from Britain was therefore central to the British World agenda. This phenomenon was indeed of immense proportions. It is estimated that in the century after 1815 approximately 22.4 million people left the British Isles, with another 3 million emigrating between 1920 and 1950. Until the turn of the century, the majority went to the United States, with a minority heading to the settler colonies. After 1900, however, this balance shifted, with most of those who left Britain between 1900 and 1950 settling within the British Empire. ${ }^{8}$ This massive demographic expansion not only shaped the lives of those who migrated from Britain but also had tragic consequences for the indigenous and preexisting communities of the lands in which they settled. Indeed, examination of indigenous and subaltern histories - together with research on the conflict and decimation colonialism brought, and the resistance and contestation it inspiredhas been among the most important work undertaken by national historians in the former Dominions in the last thirty years. However, while they recognized the significance of this work, Bridge and Fedorowich argued that settler societies were not only shaped by "grammars of difference" marked out and measured on the frontier and in contexts of contest and rule. Rather, they contended that these communities were also part of a shared British World held together by what they called a common "cultural glue." Extended along the routes of migration, this common culture "consisted not only of sentiment and shared institutional values but also of a plethora of networks."

Therefore, British World scholars have focused on the real and imagined commonalities that connected settler communities. ${ }^{10}$ In particular, they have examined a shared sense of Britishness, which they argue united people who lived in these regions. ${ }^{11}$ Although this was an identity that was most strongly held by British migrants and their descendants, historians who have taken up the British World concept suggest that it also functioned as a capacious category that could be locally adapted and embraced by those whose roots were not in the British Isles, including many nonwhites. ${ }^{12}$ For these scholars it was this shared but contested culture that was the real glue of the British Empire, a "glue" that explains the survival of notions of a

${ }^{7}$ Bridge and Fedorowich, "Mapping the British World," 11.

${ }^{8}$ M. A. Jones, "The Background to Emigration from Great Britain," in Dislocation and Emigration: The Social Background of American Immigration, ed. D. Fleming and B. Bailyn (Cambridge, MA, 1974), 3334; Stephen Constantine and Marjory Harper, Migration and Empire (Oxford, 2010); Charlotte Erickson, Invisible Immigrants: The Adaptation of English and Scottish Immigrants to Nineteenth-Century America (London, 1972).

${ }^{9}$ Bridge and Fedorowich, "Mapping the British World," 6.

${ }^{10}$ Ibid.

${ }^{11}$ Kate Darian-Smith, Patricia Grimshaw, and Stuart Macintyre, ed., Britishness Aborad: Transnational Movements and Imperial Cultures (Melbourne, 2007).

${ }^{12}$ For example, see Donal Lowry, "The Crown, Empire Loyalism and the Assimilation of Non-British White Subjects in the British World: An Argument against 'Ethnic Determinism," Journal of Imperial and Commonwealth History 31, no. 2 (May 2003): 96-120; Saul Dubow, "How British Was the British World? The Case of South Africa," Journal of Imperial and Commonwealth History 37, no. 1 (March 2009): 1-27. 
British World well into the 1950s. ${ }^{13}$ Themes of migration, common culture, and shared identity therefore undergirded the British World idea, and it was these three themes that constituted the focus of the meetings-in Cape Town in 2002, Calgary in 2003, Melbourne in 2004, Auckland in 2005, and Bristol in 2007held in the wake of the initial 1998 London conference. Edited volumes arising from these meetings have been published, and numerous article-length studies and a handful of monographs have appeared. ${ }^{14}$

But since its initial flowering, the British World approach has encountered a number of difficulties. To begin with, it has struggled with a lack of definitional clarity. Indeed, as Phillip Buckner and R. Douglas Francis wrote in their introduction to the edited volume that emerged following the 2003 Calgary meeting, "[T]he founders of the British World project were never unified in their interpretation of what should be included within [its] . . . framework."15 Yet after ten years its spatial and temporal boundaries still remained unclear. To what extent did the notion of the British World account for relations between Britain and Catholic Ireland, French Canada, or Afrikaner South Africa? What about the Straits Chinese, India, or Latin America? Or, indeed, the United States-a relationship that latterly, in the form of Atlantic World scholarship, has an older and detailed historiography? 16 After all, in the nineteenth century, these were places to which British migrants had also traveled and settled. Similarly, although there seemed agreement that the British World demised in the 1960s, questions regarding its chronology also remained unanswered. Alert to these issues, the Calgary conference sought to address questions of inclusion and membership, while the final 2007 Bristol meeting explicitly sought to map and define what was meant by the concept. Yet these events raised more questions than they solved, and a clearer framework has not emerged.

This definitional uncertainty highlights a methodological difficulty the project had faced from its beginnings. For, although the editors of the British World volumes

${ }^{13}$ Phillip A. Buckner, "Introduction: The British World," History of Intellectual Culture 4, no. 1 (2004), 3; A. G. Hopkins, "Rethinking Decolonization," Past \& Present 200 (August 2008): 211-47.

${ }^{14}$ Bridge and Fedorowich, The British World; Phillip A. Buckner and R. Douglas Francis, eds., Rediscovering the British World (Calgary, 2006); Phillip A. Buckner and R. Douglas Francis, eds., Canada and the British World: Culture, Migration, and Identity (Vancouver, 2006); Darian-Smith, Grimshaw, and Macintyre, Britishness Abroad; Phillip A. Buckner and Carl Bridge, "Reinventing the British World," Round Table 368 (January 2003): 77-88; Simon J. Potter, News and the British World: The Emergence of an Imperial Press System, 1876-1922 (Oxford, 2003); Bill Nasson, Britannia's Empire: Making a British World (Stroud, 2004); Keith Jeffery, "The Road to Asia, and the Grafton Hotel, Dublin: Ireland in the 'British World," Irish Historical Studies 36 (November 2008): 243-56; John Griffiths, "Were There Municipal Networks in the British World, c1890-1939?" Journal of Imperial and Commonwealth History 37 (December 2009): 575-97; Tamson Pietsch, "Wandering Scholars? Academic Mobility and the British World, 1850-1940," Journal of Historical Geography 36 (October 2010): 377-87; Katie Pickles, "The Obvious and the Awkward: Postcolonialism and the British World," New Zealand Journal of History 45, no. 1 (April 2011): 85-101; Arthur Downing, "The Friendly Planet: 'Oddfellows,' Networks, and the 'British World,' c.1840-1914,” Journal of Global History 7, no. 3 (November 2012): 389-414.

${ }^{15}$ Buckner and Francis, Rediscovering the British World, 18.

${ }^{16}$ David Armitage, "Greater Britain: A Useful Historical Category?” American Historical Review 104, no. 2 (April 1999): 427-45; Frank Thistlethwaite, The Anglo-American Connection of the Early Nineteenth Century (Philadelphia, 1959); David Armitage and Michael J. Braddick, The British Atlantic World, 15001800 (Basingstoke, 2002); Jack P. Greene and Phillip D. Morgan, Atlantic History: A Critical Appraisal (Oxford, 2009). 
placed an emphasis upon shared culture and identity, much of the work they collected tended to remain rooted in particular regional or national constituencies. Indeed, much British World scholarship has been more concerned with the importance that the British connection had for various national communities than it has been focused on a British World conceived of as a whole. The articulated goal of Philip Buckner and Douglas Francis's Canada and the British World, for example, was "to re-examine a complex phenomenon and to understand how it shaped the world in which Canadians lived and to some extent still live."17 With some notable exceptions-Simon Potter's News and the British World (2003) in particular stands outBritish World scholarship has for the most part proceeded through comparison and juxtaposition. ${ }^{18}$ Paradoxically, this hesitancy in joining the particular with the general has also meant that, despite their attention to provincial examples, British World case studies have tended to underplay the complications of local conditions and the contested politics of specific colonial identities. At the same time as it focuses on regional Britishness, British World scholarship can also seem to take settlers out of their specific colonial contexts and pass over the weight of local colonial entanglements. ${ }^{19}$

Underpinning both these issues is an inherent fuzziness about the mechanisms at the heart of British World connections. Although its proponents speak about "networks," with the exception of Potter's book, British World scholarship has neither traced their operation nor attended to the systems and institutions that created, sustained, and conditioned them. It has had little to say about how the British World fits within the formal and informal processes historians normally associate with British imperialism and little to say about its relationship to the wider transnational networks linking actors across the globe. Beyond its stated desire to "recover" the story of connections with the settler colonies, the project lacks a convincing conceptual or theoretical reflection of its historiographic contributions.

This absence has left the British World concept poorly placed to engage with the robust bodies of work that have emerged in the last fifteen years on settler colonialism, imperial cultures, whiteness, and race-all of which touch on its concerns in some way. ${ }^{20}$ Indeed, by "restoring British settlers to a central role in empire building," some historians have argued that the British World idea neglects the "virulently racist contribution [of these settlers] to the shaping of colonial discourses and

\footnotetext{
${ }^{17}$ Buckner and Francis, Canada and the British World. The work of historians seeking to recover the role that the various national groups from within the United Kingdom played in the story of Britain's empire might also be seen in this light. See Aled Jones and Billie Jones, "The Welsh World and the British Empire, c 1851-1939," in Bridge and Fedorowich, The British World; James Watson, "English Associationalism in the British Empire: Yorkshire Societies in New Zealand before the First World War," Britain and the World 4 (March 2011): 84-108.

${ }_{18}$ Potter, News and the British World.

${ }^{19}$ For example, see Tony Ballantyne, "Thinking Local: Knowledge, Sociability and Community in Gore's Intellectual Life, 1875-1914,” New Zealand Journal of History 44 (October 2010): 138-56.

${ }^{20}$ Patrick Wolfe, "Settler Colonialism and the Elimination of the Native," Journal of Genocide Research 8 (December 2006), 387-409; Lorenzo Veracini, Settler Colonialism: A Theoretical Overview (Basingstoke, 2010); Hall and Rose, "Introduction: Being at Home with the Empire"; Ruth Frankenberg, White Women, Race Matters: The Social Construction of Whiteness (Minneapolis, 1993); Alastair Bonnett, White Identities: Historical and International Perspectives (Harlow, 2000); Marilyn Lake and Henry Reynolds, Drawing the Global Colour Line: White Men's Countries and the International Challenge of Racial Equality (Cambridge, 2008).
} 
practices." 21 As Saul Dubow has pointed out, some critics have even suspected that the project "is merely a dressed up form of the old imperial history, or worse, that it recalls the racially inflected nineteenth-century vision of 'Greater Britain."'22 Phillip Buckner and Douglas Francis have rejected such claims, arguing that the movement was not a lament for a lost world but rather an attempt to understand a complicated phenomenon that had been neglected by imperial historians. ${ }^{23}$ But in accentuating the shared culture and identity of settler communities and their connections with Britain, the British World approach can be seen to have de-emphasized the uneven nature of power relations, both within these societies themselves and between British settlers and those cast as their racial, ethnic, and religious "others." This tendency to flatten out fissures and frictions, and to focus on Britishness, has worked to obscure the ways such identities helped to normalize the practices of settler colonialism, while simultaneously sidelining issues of power, access, difference, and contest within colonial societies and overlooking the complex lateral interconnections between the settler, commercial, and dependent parts of Britain's empire.

Finally, despite its stated interest in culture and identity, the British World approach has seemed reluctant to engage with scholarly developments emerging under the aegis of the "new cultural" and the "new political" history. ${ }^{24}$ This has, to be sure, involved a distancing of itself from the new imperial historians' interest in otherness and difference. But it has also entailed a lack of any explicit interaction with the turn, in the past two decades, to consideration of the complex ways in which meanings are constructed, received, and sustained, not just, as Jay Smith writes, "by semiotic context but also by the collective and value-laden assumptions of the people who constitute society." 25 Such attention to the produced nature of meaning involves concern as much with the multiple ways in which meanings were debated and contested as with the ways they were established. In the case of the new political history, this means examining not only states and political organizations but also the cultures of politics that helped constitute them. In the face of these criticisms, a decade after its inception, British World scholarship seemed to have stuttered to a halt.

However, in advancing the idea of a British World that stretched between dispersed parts of the globe, these historians were in many ways wrestling with the same problem that since the late 1990s had been animating scholars across the humanities and social sciences and forcing them to reconsider the way they thought about

${ }^{21}$ Alan Lester, "Imperial Circuits and Networks: Geographies of the British Empire," History Compass 4, no. 1 (January 2006): 130.

${ }^{22}$ Dubow, "How British Was the British World?", 2. Dubow is perhaps referring to Tony Ballantyne's contention that the "use of 'Britishness" as an analytical apparatus not only marks a return to C.W. Dilke's celebration of Britishness and empire but also is an impoverished and reductive model for the history of multiethnic and polyglot colonial societies for removed from the United Kingdom. See Tony Ballantyne, Orientalism and Race: Aryanism in the British Empire (Basingstoke, 2001), 3.

${ }^{23}$ Buckner and Francis, introduction to Rediscovering the British World, 18-19.

${ }^{24}$ Aletta Biersack and Lynn A. Hunt, eds., The New Cultural History (Berkeley, 1989); Lawrence Black, "What Kind of People Are You?' Labour, the People, and the 'New Political History," in Interpreting the Labour Party: Approaches to Labour Politics and History, ed. John Callaghan, Steven Fielding, and Steve Ludlam (Manchester, 2003), 23-38.

${ }^{25}$ James Epstein, "Introduction: New Directions in Political History," Journal of British Studies 41, no. 3 (2002): 255-58; Jay M. Smith, "No More Language Games: Words, Beliefs, and the Culture of Early Modern France," American Historical Review 102, no. 5 (December 1997): 1439. 
their disciplines. This was the problem of increasing global connection-its origins and growth, its limitations, and its consequences. Indeed, it is an attempt to understand the workings and development of globalization that in the last few years has led scholars to again turn their attention to the history of mass migration from Britain. From Niall Ferguson to James Belich, several historians have argued that this outflow of people was a key driver of global connection. ${ }^{26}$ Gary Magee and Andrew Thompson have seen it as a force that shaped economic activity, while Duncan Bell and David McIntyre have understood British settler societies as central to political ideas that sought to make sense of a changing geopolitical landscape. ${ }^{27}$ Together, the appearance of these works suggests that the time is ripe to revisit the concept of the British World in the light of the criticisms it has faced and examine its utility for scholars seeking to understand the history of empire and its relationship to the global.

This article begins this undertaking by drawing on recent scholarship associated with the social and material production of space. It argues that just as geographers have come to understand space not as a fixed entity that we move through but rather as something that gets made by people and their contexts, so historians of Britain and its empire need to think not of a singular British World but rather of multiple, produced British world spaces: we need to think not only about the places in which people lived but also about the networks and exchanges that shaped their lives and the emotions and feelings that created internal landscapes of longing and belonging. ${ }^{28}$ These were British worlds that stretched in directions that sometimes but not always overlapped; worlds that warped and shaped each other, fashioning uneven transnational realms that were global but by no means universal. Conceptualizing these British "worlds" offers historians a way of thinking about the limited, affective, and often exclusionary spaces that characterized and still characterize globalization. Indeed, this article suggests that if we pay attention to the voices of those who at the turn of the twentieth century spoke about the "British world"-people who themselves were experiencing the changes brought about by dramatic new forms of global connection-we find them talking in just this way.

\section{NETWORKS AND THE SPACES OF GLOBAL CONNECTION}

Cognizant of contemporary globalization, in the last fifteen years scholars from a wide range of disciplines have begun to think more broadly about the transnational

\footnotetext{
${ }^{26}$ Ferguson calls it "Anglobalization"; Belich, the "settler revolution." Niall Ferguson, Empire: The Rise and Demise of the British World Order and the Lessons for Global Power (New York, 2003); James Belich, Replenishing the Earth: The Settler Revolution and the Rise of the Anglo-World, 1783-1939 (Oxford, 2009); John Darwin, The Empire Project: The Rise and Fall of the British World-System, 1830-1970 (Cambridge, 2009).

${ }_{27}$ Gary Bryan Magee and Andrew S. Thompson, Empire and Globalization: Networks of People, Goods and Capital in the British World, c. 1850-1914 (Cambridge, 2010); Duncan Bell, The Idea of Greater Britain: Empire and the Future of World Order, 1860-1900 (Princeton, NJ, 2007); W. David McIntyre, The Britannic Vision: Historians and the Making of the British Commonwealth of Nations, 1907-48 (Basingstoke, 2009).

${ }^{28}$ A key work here is Edward W. Soja, "The Socio-spatial Dialectic," Annals of the Association of American Geographers 70, no. 2 (June 1980): 207-25, in which Soja argued that "social and spatial relations are dialectically inter-reactive, interdependent." See also E. Soja, Postmodern Geographies: The Reassertion of Space in Critical Social Theory (London, 1989); Doreen Massey, For Space (London, 2005); Michael J. Dear and Steven Flusty, eds., The Spaces of Postmodernity: Readings in Human Geography (Oxford, 2002).
} 
and global connections of the modern world. In particular, they have pointed to the importance of various kinds of networks in moving people, products, and information around the globe. ${ }^{29}$ Historians of the British Empire have enthusiastically adopted this "network approach," seeing the extension of new communications and transportation technologies such as steamships and undersea telegraph cables in the second part of the nineteenth century as especially important both in building transnational identities and in forging colonial rule. ${ }^{30}$ Indeed, attention to networks has been a feature of British World scholarship. But, as noted above, much of this work emphasized the integrative nature of networks and highlighted the extent to which they flattened out other kinds of distance, bringing settler communities into close connection with Britain.

The networks of the late nineteenth and early twentieth centuries, however, were - like those of today-contingent things. They stretched across space, but not all space; they connected people, but not all people; they burst into life, but they also died. As Simon Potter has argued, "Patterns of long-distance mass communication in the nineteenth- and twentieth-century British Empire were influenced by particular institutions and marked by an unevenness and a tendency towards systematization that shaped the nature and the extent of connections between different parts of the world." 31 The questions we need to ask when we consider networks must, therefore, focus on the nature of these contingencies, on the factors and processes that shaped them, and on their consequences. ${ }^{32}$ They must focus on the unequal ways networks were used, on who employed them, and for what multiple and conflicting ends, and they must address the ways in which networks changed over time. If networks of trade, communication, and transportation brought far-flung parts of the world into close connection with each other, they did so in a highly uneven manner.

These transnational networks and the connective infrastructures that facilitated them shaped the ways people experienced space and the ways in which they understood it. If the life of a particular community was dependent upon connection with places remote to it - as Sandip Hazareesingh has shown the port of Glasgow was tied up with Bombay, for example - then in very real ways those places and the people who lived in them were brought close together, becoming interdependent in ways that remade alignments of proximity and distance. ${ }^{33}$ Similarly, the transportation

${ }^{29}$ Manuel Castells, The Rise of the Network Society (Oxford, 1996); Ann L. Stoler and Frederick Cooper, "Between Metropole and Colony: Rethinking a Research Agenda," in Tensions of Empire: Colonial Cultures in a Bourgeois World, ed. Ann L. Stoler and Frederick Cooper (Berkeley, 1997); Saskia Sassen, Globalization and Its Discontents (New York, 1998); Saskia Sassen, ed., Global Networks, Linked Cities (New York, 2002).

${ }^{30}$ John B. Thompson, The Media and Modernity: A Social Theory of the Media (Cambridge, 1995), 8. For the importance of networks to imperial history, see Christopher A. Bayly, Empire and Information: Intelligence Gathering and Social Communication in India, 1780-1870 (Cambridge, 1996); Alan Lester, "British Settler Discourse and the Circuits of Empire," History Workshop Journal 54, no. 1 (Autumn 2002): 24 48; Ballantyne, Orientalism and Race, 12, 195; Simon J. Potter, "Webs, Networks and Systems: Globalization and the Mass Media in the Nineteenth- and Twentieth-Century British Empire," Journal of British Studies 46, no. 3 (July 2007): 621-46.

${ }^{31}$ Potter, "Webs, Networks and Systems," 622.

32 Charles Maier in Ian Tyrrell, "Reflections on the Transnational Turn in United States History: Theory and Practice," Journal of Global History 4, no. 3 (November 2009): 467; Simon J. Potter, "Empire, Cultures and Identities in Nineteenth- and Twentieth-Century Britain," History Compass 5, no. I (January 2007): 58.

${ }^{33}$ Sandip Hazareesingh, "Interconnected Synchronicities: The Production of Bombay and Glasgow as Modern Global Ports, c. 1850-1880,” Journal of Global History 1, no. 4 (March 2009): 7-31. 
of people, goods, and ideas along these routes shaped the feelings and emotions of individual men and women. Longing for home, anxiety about the future, and anger at poor treatment fashioned personal spaces that, although interior, intersected with and acted upon the circulating material world just mentioned. Both these spaces in turn helped form the localities in which people lived and the sites through which goods traveled-the docks, the woollen mills, and the interiors of homes; what people ate, how they voted, and where they spent their money.

This is what geographers mean when they talk about the social and material production of space. For historians unfamiliar with this work, David Harvey's tripartite definition is perhaps a helpful place to begin. Harvey talks about three kinds of space: absolute, relative, and relational. According to him, absolute space is bounded and immovable. It is space as we might commonsensically understand it-locatable, measurable, and fixed. In contrast, relative space is the space of processes and motions. It is the space "of transportation relations and of commodity and monetary circulation"- a space that can be mapped differently depending on whether we are measuring cost, time, type of commodity, or mode of travel. ${ }^{34}$ Finally, relational space is the space that lives inside us - the space produced by our experiences, memories, fears, and dreams. It is a space that is difficult to measure, in which identity is fluid and multiple. ${ }^{35}$ According to Harvey, none of these frames alone is sufficient to explain the world and people's experience of it. Rather, they exist in tension with each other: "[W]e are inexorably situated in all three frameworks simultaneously, though not necessarily equally so."36

Harvey first put forward these ideas in 1973, seeing such reflections on the nature of space as crucial to understanding the inequalities and injustices of "urban processes under capitalism"-not only do social relations shape space, he argued, but planners seek spatial forms that will shape social behavior. ${ }^{37}$ To buttress this contention that we live in a world produced in a myriad of complex ways, Harvey placed his tripartite division of space alongside Henri Lefebvre's own threefold understanding. ${ }^{38}$ Space, Harvey wanted to make clear, is always a complex of relational, relative, and absolute aspects. This assumption is central to his argument that global capitalism works by distancing itself from the relational ways-lived, felt, dreamed, and imagined-in which humans experience space and instead seeks to operate solely within the realms of absolute and relative space-the spaces of trade and exchange. ${ }^{39}$

Arguments such as these have particular resonance for historians interested in the relationship between mass migration and the workings of globalization in the late

${ }^{34}$ David Harvey, Cosmopolitanism and the Geographies of Freedom (New York, 2009), 135. See also "Space as a Key Word," in David Harvey, Spaces of Global Capitalism: Toward a Theory of Uneven Geographical Development (London, 2006), 119-48.

${ }^{35}$ Harvey, "Space as a Key World," 128.

36 Ibid., 277.

${ }^{37}$ David Harvey, Social Justice and the City (London, 1973); Harvey, "Space as a Key Word," 120.

${ }^{38}$ Lefebvre speaks about (1) material space (spaces as experienced through our sense perceptions), (2) the representation of space (the way we conceive and represent this world of experienced sense perceptions), and (3) what he calls the "spaces of representation" (the way we live in and through the spaces we perceive and conceive). For Lefebvre, then, space is inherently imbued with the traces of the processes that produced it. See Harvey, Cosmopolitanism and the Geographies of Freedom, 141-65.

${ }^{39}$ Eric Sheppard, "David Harvey and Dialectical Space-Time," in David Harvey: A Critical Reader, ed. Noel Castree and Derek Gregory (Oxford, 2006), 121-41. 
nineteenth and early twentieth centuries, for this was a period in which the world was becoming connected in new kinds of ways. From the 1840s railways began to stretch across continents, and from the 1860s steam-powered ocean vessels crossed the Atlantic. Following the opening of the Suez Canal in 1869, by the 1880s steam ships had taken over the longer-range routes to Australasia and East Asia as well, dramatically reducing both the time and the cost of travel. The transatlantic crossing, which had formerly taken thirty days, now took as little as ten; the trip to Australia fell from three months to one; and the voyage from London to Bombay was halved. Freight prices dropped by 90 percent. ${ }^{40}$ Meanwhile, from the 1860 s, undersea telegraph cables connected Britain to India and North America, and from the 1870s to Australasia as well. These routes not only enabled people, information, and goods to move around the world in larger numbers than ever before but also brought far-away places deep into domestic cultures. Yet they did so in ways that were highly uneven. At the same time as the new connective infrastructures linked some parts of the world, they also created fresh alignments of exclusion and isolation. In addition, although the new kinds of transport and communication reshaped some of the older "global" worlds fashioned by religion, trade, and language, they never wholly penetrated or replaced them. To understand the worlds created by Victorian globalization, we need to attend to the absolute, relative, and-most importantrelational spaces in which contemporaries lived. We need to consider how they experienced the new imperial and global connections of the period and the ways they sought to make sense of them.

\section{THE BRITISH WORLDS OF THE 1903 ALLIED COLONIAL UNIVERSITIES CONFERENCE}

The proceedings of the 1903 Allied Colonial Universities Conference offer a good opportunity to take up these questions. The history of the connections among the universities of the British Empire is a subject that has so far been curiously neglected by historians of education and imperialism alike. ${ }^{41}$ Yet, like the international scientific congresses and traveling meetings of the British Association for the Advancement of Science (which have attracted considerable attention), the history of academia offers scholars a way of examining the relationships between culture, knowledge, and empire in the nineteenth and twentieth centuries. ${ }^{42}$

Founded in the middle of the nineteenth century, many of the universities in India, Canada, Australia, New Zealand, and South Africa predated the establishment of the English civic or redbrick institutions. However, while those on the subcontinent were set up by British officials (as, later, were those in Africa), the universities in what would become the Dominions were founded by self-confident settler elites

\footnotetext{
${ }^{40}$ Daniel R. Headrick, The Tools of Empire: Technology and European Imperialism in the Nineteenth Century (New York, 1981), 167; Belich, Replenishing the Earth, 108.

${ }^{41}$ I take up these connections in detail in Tamson Pietsch, Empire of Scholars: Universities, Networks and the British Academic World, 1850-1939 (Manchester, 2013).

${ }^{42}$ For example, see Roy MacLeod and Peter Collins, eds., The Parliament of Science: The British Association for the Advancement of Science, 1831-1981 (Northwood, 1981); Charles Withers, Geography and Science in Britain, 1831-1939: A Study of the British Association for the Advancement of Science (Manchester, 2010).
} 
who saw these institutions as both symbols of colonial maturity and disseminators of European civilization in the colonies. Drawing their staff predominantly from the United Kingdom, since the 1880s these settler institutions had sought to cultivate closer ties with British scholarship, sponsoring traveling scholarships for their graduates and leave of absence schemes for their staff, and employing appointment processes that plugged their academics into British networks. Universities both in Britain and in the settler colonies accorded official recognition to the "British academic world" these scholarly ties created by granting preferential standing to each other's degrees. Yet despite these various informal connections, until 1903 there had been no attempt to bring together representatives of the universities of the empire.

In fact, the initiative for the 1903 Allied Colonial Universities Conference came not from the universities but from the Canadian novelist and Conservative member of the Parliament of the United Kingdom for the constituency of Gravesend (in Kent), Sir Gilbert Parker. In November 1902, having attended a dinner in London for graduates of Trinity University, Toronto, Parker decided to host a similar dinner for all colonial university graduates resident in England. ${ }^{43}$ But in the heady political climate that erupted following the tariff reform speech delivered in May 1903 by his fellow Conservative parliamentarian Joseph Chamberlain, Parker's event offered the possibility of embodying the very kind of imperial union both wished to promote. ${ }^{44}$ What began as a dinner for colonial graduates therefore grew to resemble an Edwardian imperial convention, complete with the round of parties and "inevitable dinner[s]" such an event usually entailed. ${ }^{45}$ Like other imperial groups that, at the turn of the century, turned to the idea of sentimental union in the wake of the failure of imperial federation, the 1903 conference sought to institute schemes that would foster what it saw as the already existing cultural and ideological affinity between Britain and the settler colonies. ${ }^{46}$ Education was a common focus of these groups, and the Imperial Studies Group (c. 1887), the Victoria League (1901), and the League of the Empire (1901) all emerged in this period. However, although the 1903 conference must be seen in this context of the concern with Greater Britain that Duncan Bell has suggested grew as a response to the contemporary anxieties about social and economic decline in Britain, it instigated a movement for university association that has endured. ${ }^{47}$ Followed by the Congresses of the Universities of the British Empire, held in 1912, 1921, and then every five years throughout the interwar period, the movement found permanent institutional form in the Universities Bureau (now the Association of Commonwealth Universities), which kept an office in London. ${ }^{48}$

\footnotetext{
${ }^{43}$ Letter concerning the Allied Colonial Universities Dinner, from E. N. Fere and L. C. R. Arnott (Hon. Secs.), 15 January 1903, Registrar's Correspondence, Series 200, 1903/156, University of Adelaide Archives.

${ }^{44}$ Bryce, in "Official Report," 77. See also Pietsch, Empire of Scholars, 94-99.

45 "The Allied Colonial Universities Conference," The Times, 13 July 1903, 9.

46 James Greenlee, "The ABCs of Imperial Unity," Canadian Journal of History 14, no.1 (April 1979): 49.

${ }^{47}$ Duncan Bell, The Idea of Greater Britain: Empire and the Future of World Order, 1860-1900 (Princeton, 2007).

${ }^{48}$ For more on the 1903 conference, the congresses and the Universities Bureau see Tamson Pietsch, "Mending a Broken World": The Universities and the Nation, 1918-36," in Brave New World: Imperial and Democratic Nation-Building in Britain between the Wars, ed. L. Beers and G. Thomas (London,
} 
The 1903 conference is a useful case study because, as institutions that were rooted in specific social and political communities and yet were also agents of "universal" culture and scholarship, universities and those who worked in them were especially conscious of their place at the nexus of the local and the global. The imperial rhetoric of the 1903 meeting tells us much about the ways those who lived along the routes of empire understood their world. It reveals participants' multiple, limited, and overlapping notions of the British world and shows them articulating various notions of space that echo Harvey's tripartite division.

\section{Material Connection}

Conference delegates articulated a British world linked by material connections-a British world fashioned in what Harvey would call relative space. As F. H. Chase, a professor of divinity at the University of Cambridge, asserted at the start of the meeting, "These universities are already connected. We have not to create an affinity between them." 49 Participants-who included politicians, educationalists, and academics from across Britain and the British settler empire, all of whom were menidentified a community made by tangible ties that linked those working in colonial universities to each other and to their colleagues in Britain: "We are bound up with each other," said Thomas Harrison of the University of New Brunswick, "the younger with the older Universities." 50

Mostly loudly asserted in 1903 was the reality of what was called "interchange"the movement and circulation of students and staff between universities. "Already we have a considerable interchange of professors," declared James Bryce in the opening session. ${ }^{51}$ Sir Henry Roscoe, former vice-chancellor of the University of London, agreed. He assured the meeting that he could "give a long list of scholars who are now distinguished, who hold professorships in various parts of the Empire." 52 Indeed, the lives of many of the delegates at the conference were themselves testament to academic migration. A large contingent of them had traveled from Britain to academic positions in various colonies. As the University of Sydney's Theodore T. Gurney noted, his institution had "on its staff graduates of almost every university." The careers of men like Samuel Alexander, Grafton Elliot Smith, and Ernest Rutherford were cited as examples of the migration of scholars from the New World to the Old. ${ }^{53}$ Similarly, conference participants were also quick to point out that there was a considerable circulation of colonial students. For example, Dyce Duckworth from Edinburgh boasted that he represented "a University which is know $[\mathrm{n}]$ for many years to have opened her doors perhaps more largely to Colonial students than any other in the three Kingdoms." 54

\footnotetext{
2011), 161-80; Tamson Pietsch, "Out of Empire: The Universities' Bureau and the Congresses of the Universities of the British Empire, 1913-1939," in Universities for a "New World": A Commonwealth of Knowledge and Skills, 1913-2013, ed. D. Schreuder (Sage, forthcoming 2013).

49 “Official Report," 78.

50 Ibid., 117.

${ }^{51}$ Ibid., 74.

52 Ibid., 85.

53 Ibid., 95, 101.

${ }^{54}$ Ibid., 111, 113-14.
} 
In addition to the movement of people, the conference participants also highlighted the movement of objects in the form of examination papers. Chase spoke of the Cambridge system of local examinations, in which entrance exams could be sat in designated centers around the empire. ${ }^{55} \mathrm{H}$. Dean Bamford from the University of New Zealand spoke of his institution's practice of selecting the "foremost men in England" to "set and correct" its examinations, the papers for which were shipped over to Britain each year, while Principal W. Peterson from McGill University highlighted his institution's policy of "holding, for some years past, matriculation examinations in London." "[A]s a matter of fact," declared Richard Threlfall representing Sydney, "[i]f we look it up we shall find that it is already possible for any student to go to any other University that gives privileges." 57 The conference delegates knew that this movement of people and objects between the universities of Britain and the settler world connected places that physically were located far apart. But they also knew that these material networks extended to certain institutions and not others: for the most part, teachers did not travel to the United States; exam papers were not sent to Germany; and colonial students went mostly to Edinburgh, Oxford, Cambridge, and London. ${ }^{58}$ For the delegates in 1903 this was a kind of British world that already existed-one mapped by the tangible flows of material connection. Its borders, its centers, and its peripheries were determined not by political boundaries or physical distance but rather by the relative movement of people, exam papers, and regulatory policies.

\section{An Imagined Community}

But the conference participants' personal experience of movement along the routes of this relative British world led many of them to imagine another kind of British world - one marked out in what Harvey would call relational space. Those who attended the meeting placed a strong emphasis upon their feelings of affinity. Bryce opened the meeting by talking about the "identity of thought and feeling, a like attachment to those glorious traditions which link us to the past, a like devotion to those ideals which we have to pursue in the future."59 The educational reformer and Liberal imperialist R. B. Haldane spoke of a "common sentiment," while Peterson in Canada alluded to the "feeling of brotherhood" that pervaded the room. ${ }^{60}$ Responding to their own experience of relocation, to anxieties about British decline, and to their feelings of belonging, in different ways the delegates imagined a British world that extended out beyond the confines of the British Isles.

Like many of their contemporaries, the conference participants imagined this British world as a community defined by race. F. H. Chase from the University of Cambridge spoke of the "unity of race, unity of language, unity of character, and . . . unity of religious ideas," while the Conservative prime minister Arthur Balfour boasted of the "British people throughout the world" as a "community of

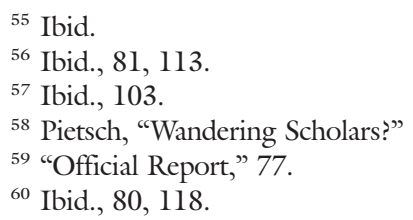


blood."61 According to Haldane, it was a racial community with very particular characteristics: "We have got the splendid energy of our race," he proclaimed, "we have got the power which is ours, in a unique degree, of adapting ourselves to new conditions, of overcoming difficulties which to others might even seem to be insurmountable."62 Given this racial imagining, it is perhaps unsurprising to find that the Indian universities were not invited to the 1903 meeting and that the laws, literature, and energy that Haldane saw as native to the "British peoples" were portrayed as "foreign to the East." 63

However, if the British world was to be imagined as a racial community, where did that place the United States? It was, after all, a country to which large numbers of British people had migrated, but it stood outside the bounds of the British Empire and by the turn of the century was emerging both as a direct global and economic challenge to British supremacy and as a potential complementary power. For the 1903 conference participants, the United States stood as a testament to the energy and vitality of the British race, but it also constituted a threat to it. On the one hand, they spoke of the United States as part of an Anglo or English-speaking world, and on the other, they talked about it as a rival to a more narrowly conceived British community. ${ }^{64}$

Alongside this racially demarcated community, conference participants also imagined an educational world that was part of the larger world of "universal" scholarship: "No jealous tariffs stand between the free communication of ideas," argued Balfour at the 1903 meeting, "[a]nd surely we may be happy that that is the fact." 65 Yet despite these cosmopolitan pronouncements, the delegates nonetheless marked out a special British sphere within the international community of scholars. As Balfour continued:

though knowledge is cosmopolitan, though science knows no country and is moved by no passions not even the noblest passion of patriotism still I do think that in the methods and machinery of imparting knowledge, as there always has been in modern times, so there should still continue to be some national differentiation between the centres of knowledge which reflects the national character and suits the individual feeling, and that . . . an English-speaking student and a citizen of the Empire from whatever part of the world he may hail, ought to find something equally suited to him as a student, and more congenial to him as a man, in some university within the ample bounds of the Empire. ${ }^{66}$

Chase spoke of the universities as "sisters," Peterson called them "fellow-workers," and Manchester's Alfred Hopkinson argued that the British universities at home and abroad were part of "one great commonwealth in learning and in science." 67 With F. B. Jevons, the subwarden of the University of Durham, they looked "forward

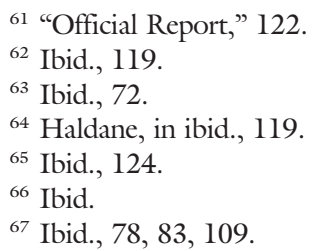


to a time when there shall be one corporation of learning throughout the whole British Empire."68

At the 1903 conference, these severally imagined British worlds were expressions of the feelings of connection to which delegates repeatedly testified. They overlapped and spilled into each other, and their boundaries were neither wholly consistent nor especially well defined. Often they were deeply contested. These imagined British worlds frequently drew on the conceptual apparatus of other imagined worlds (of which a more broadly conceived empire, religious community, global "Scottishness," and sense of cosmopolitan internationalism were just some) or defined themselves in opposition to rival configurations (such as republican nationalism or international socialism) borrowing as well as lending their ideational power. But together they point to the various ways in which individuals at the turn of the century conceived of a British world that was an idealized union-a community of sentiment and feeling that existed in their heads and in their hearts.

\section{Local Variations}

Third, the 1903 conference participants spoke of a British world of numerous and divergent local sites-sites we might understand within Harvey's frame of absolute space. Chase, for example, knew that "inherited tradition" was "modified in the light of experience" to create "many types of universities" and that "the type of a university is largely determined by its previous history and by its environment." 69 For him, and for his fellow delegates, there were many local British worlds, characterized by "differences of type." "70 As Haldane explained, "[T] he soil, the climate, the tastes of the people, yes, and the commercial aspirations of the people . . these are the root and source of much of the energy which is thrown into education [and $t$ ] hese aspirations, varying in different places, all tend to give a different complexion-a different intellectual complexion - to the University feeling in each locality." "I In many ways the delegates saw this heterogeneity as a source of strength. "We must co-operate," suggested Oliver Lodge, "not by uniformity, but rather by the opposite, by differentiation." 72 The proposal was for what the conference organizers called "specialisation."73 "My dream," announced Haldane, "is to see this great British nation in its different parts, with its great common constitution, co-operating for a common end, but co-operating with the developments which are peculiar to the soil and to the branches of the people." 74

Despite these professions of cooperation, however, delegates knew that heterogeneity did not mean equality. This was demonstrated clearly by the exclusion of the Indian universities and also drawn out by the comments of several representatives at the meeting. Some noted that, although colonial universities gave full recognition to degrees from universities in Britain, Oxford and Cambridge only gave one year's

\footnotetext{
${ }^{68}$ Ibid., 116

69 Ibid., 79.

70 Ibid.

${ }^{71}$ Ibid., 117

72 Ibid., 93.

73 Ibid., 79.

${ }^{74}$ Ibid., 118.
} 
credit to graduates of colonial universities - and then only to some of them. ${ }^{75}$ "[T]here was . . a suspicion," suggested Sydney's Richard Threlfall, "that the standard of some Colonial Universities was not as high as the standard of Universities in [England]."76 Neither was it just colonial universities that had difficulties with Oxford and Cambridge. Oliver Lodge, principal of the University of Birmingham, found it galling that the degrees of his university were not recognized either. ${ }^{77}$ But perhaps it was John Watson from Queen's University in Ontario who expressed this sense of regional variation best when he explained that "you come to realise much more fully and forcibly what it is to belong, or not to belong, to an Empire when you come from a Colony than when you are at home. . . . [I] t makes quite a difference to stand at the circumference and to stand at the centre when you are considering a question of Empire." 78 With his fellow delegates, Watson recognized the divergent local variants of British universities in the settler colonies. His comments point to another type of British world-one in which the imagined communities and material connections noted above manifested in ways specific to the various absolute sites and locations of British settlement.

The participants at the 1903 Allied Colonial Universities Conference knew there was not just one kind of British world. They asserted its existence as a material reality, articulated it as an idea and a feeling, and acknowledged and incorporated its local variations. Intimately familiar with the new connective infrastructures of the period, they searched for ways to give expression to their own experience of them. They knew that there was a world mapped by the relative movement of people and objects; they knew there were internal relational worlds made by their own feelings, memories, fears, and dreams; and they knew that in various absolute sites of the settler world, these material and imagined worlds combined in different and specific ways.

As we have seen, the delegates who attended the 1903 meeting understood these worlds as British. Indeed, in many ways the Allied Colonial Universities Conference, and the whole Greater Britain movement, constituted an attempt to bring these various British worlds together and make them, in the words of F. H. Chase, "effective for practical purposes." 79 This was a project that was-at the conference as more broadly - ultimately destined to fail. But its lack of success should not blind historians to the multiple configurations of lived experience it sought to combine. For it was the means by which the 1903 delegates and many of their contemporaries sought to make sense of the uneven and limited forms of global connection that shaped their own lives.

Crucially for the delegates, as for Harvey, the multiple British worlds that framed their lives could not be separated. Migrants moved in and out of local communities, bringing with them not only relative flows of objects, goods, and money, but also their various hopes and anxieties, which in turn took on different forms in different places. Moving people acted to enshrine the worlds they imagined, in turn exerting influence over the extension of relative connections and shaping relational cultures

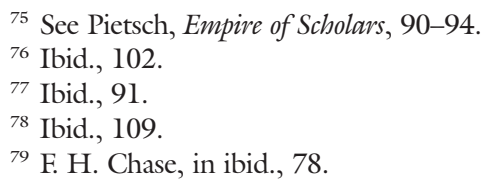


that affected not only those who saw themselves as British but also those against whom Britishness was defined-people for whom empire meant something very different indeed. The British worlds concept is useful for historians because it provides a way of talking about the multiple and intersecting yet necessarily limited worlds that long-distance connections created.

\section{POSSIBILITIES}

Much British World scholarship already implicitly recognizes this framework. Work on migration, for example, is key to understanding the British world of relative connections, while Lisa Chilton's study of female emigration promoters and Ged Martin's examination of the idea of imperial federation invoke imagined and relational British worlds. Meanwhile, Schreuder and Ward's Australia's Empire and Buckner's Canada and the British World clearly address the local manifestations of Britishness in different settler communities. ${ }^{80}$ Making the British worlds framework explicit, however, brings a number of benefits.

First, it permits a more precise understanding of what we might think of as the British World, highlighting the extent to which its boundaries depend on what we measure. There were multiple British worlds: the relative worlds mapped by the movement of goods and people between Britain and parts of the world that looked primarily to it; the relational worlds made by the not always compatible imagined visions of a common racial, linguistic, or cultural British or Anglo-Saxon community; and the local and situated worlds, enshrined and expressed in various places across the globe. Perhaps these worlds overlapped most in the settler colonies of Canada, Australia, New Zealand, and to a lesser extent South Africa, but they never did so wholly or even exclusively, and they extended variously in other directions. This approach gives us a way to think about people and communities within the United States, Argentina, British Malaya, and other places outside the Dominions, which we might understand as being part of some of these British worlds but not others. ${ }^{81}$ But it also makes space for those aspects of the history of the Dominions that do not fit this framework and for their specific and local character. This in turn makes it possible to think about a British worlds chronology. We can chart the making and unmaking of the connective institutions, racial imaginings, and local sites that helped constitute British world spaces, and we can pinpoint transformations brought to them by events such as war, economic depression, and the advent of new technologies.

Second, by seeing these British worlds as species of the relative, relational, and absolute spaces made by different kinds of global connection, this framework places the notion of the British World alongside and in tension with the other ways of navigating global space that emerged in the late nineteenth century. In

\footnotetext{
${ }^{80}$ Lisa Chilton, "A New Class of Women for the Colonies: The Imperial Colonist and the Construction of Empire," Journal of Imperial and Commonwealth History 31, no. 2 (May 2003): 36-56; Ged Martin, "The Idea of "Imperial Federation," in Reappraisals in British Imperial History, ed. Hyam and Martin (London, 1975), 121-39; Deryck M. Schreuder and Stuart Ward, Australia's Empire (Oxford, 2008); Buckner and Francis, Canada and the British World.

${ }^{81}$ Robert A. Bickers, ed., Settlers and Expatriates: Britons over the Seas (Oxford, 2010). For an earlier period, see Miles Ogborn, Global Lives: Britain and the World, 1550-1800 (Cambridge, 2008).
} 
different ways, anticolonial nationalism, international socialism, and pan-Arabism might all be seen as means by which contemporary actors sought to understand and respond to the forces of Victorian globalization. As the excellent work of many historians has recently shown, the advent of railways, the telegraph, steam ships by the 1870s and 1880s, and the political and economic possibilities and consequences they entailed affected people of all kinds from many places. ${ }^{82}$ If the notion of an expansively framed British World was a way that many Britons at home and abroad (and possibly some non-Britons as well) sought to make sense of these changes, others looked to different notions of global community in this period. The comments of J. A. Hobson in 1906 provide a good example. He noted that with the facilitation of travel and of news, the world had become "as large as we by our practical experience and our imaginative experience and sympathy choose and are able to make it" and argued that this "practical enlargement of the world" should lead, not to imperialism, but rather to democratic internationalism. ${ }^{83}$

Third, this framework provides a way of talking about power and inequality, both within the British settler world and also more broadly. For it is at the intersection of the material, imagined, and local worlds of countless people that the uneven landscapes of global connection and the unequal cultures of empire and colonial society were and are made. These worlds acted on and refashioned each other in a variety of different ways, distorting the free movement of goods, forging ideas and identities and cultures of rule, and producing sites and societies with specific characters and tendencies. Thinking in this way might bring the notion of British worlds into conversation with work on gender, race, and class, work on violence, and work on the various regimes of legislation and control (and resistance to them) that also characterized the making of the modern world.

The 1903 conference delegates were well aware that the various British worlds they apprehended intersected. Their consciousness casts light on existing scholarship and illuminates possibilities for future work. First, the 1903 delegates knew that the movement of people and objects between universities was fashioned by both sentiment and self-interest. Imagining themselves as part of an expansive British community, the universities of the settler colonies looked almost exclusively to Britain for their staff and for their educational models, but they adapted these and refashioned them to meet the particular needs of local communities. This interplay between the local and the imagined in turn conditioned the material traffic of staff, students, and syllabi. ${ }^{84}$ As historians, we need to ask questions about the ways in which the relative spaces of nineteenth- and early twentieth-century globalization that were marked out by the movement of commodities, manufactured goods, news, material culture, money, and people were shaped and warped by globalization's local and relational

${ }^{82}$ For example, see Chris Bayly, The Birth of the Modern World, 1780-1914: Global Connections and Comparisons (Oxford, 2004); Tony Ballantyne, Between Colonialism and Diaspora: Sikh Cultural Formations in an Imperial World (Durham, NC, 2006); Elleke Boehmer, Empire, the National, and the Postcolonial, 18901920 (Oxford, 2005); Isabel Hofmeyr, The Portable Bunyan: A Transnational History of the Pilgrim's Progress (Princeton, NJ, 2004).

${ }^{83}$ J. A. Hobson, "The Ethics of Internationalism," International Journal of Ethics 17, no. 1 (October 1906): 16

${ }^{84}$ Pietsch, "Wandering Scholars?" 
spaces: the particular character and needs of situated communities and the imagined worlds of their inhabitants.

We can see the importance of this question in two studies that consider the limited nature of imperial networks. In his book on the distribution of news in the British Empire, Simon Potter has shown how the high cable charges set by private telegraph companies "acted to modify and in many ways limit the impact" of the benefits in speed they brought, creating "patterns of interconnection that were quite different in nature from the unstructured, diverse, competing, and somewhat chaotic imperial webs and networks" of the first part of the nineteenth century. ${ }^{85}$ This happened, Potter argues, because local newspapers banded together to extract more favorable rates from the international news agencies that sold news content to multiple subscribers. In the case of the British Empire, it was Reuters that dominated. The emergence of these alliances worked to regulate and significantly limit the variety of news circulating around the "imperial press system," advantaging those countries such as Australia and South Africa that operated effective cartels and disadvantaging others in Africa and East Asia that did not. ${ }^{86}$ In the case of the imperial press, "[i]nstitutional agglomerations of power" in the form of business interests acting upon their need to meet the demands of specific local markets were crucial factors that shaped and restrained relative networks of communication. ${ }^{87}$

Where Potter sees institutional interests as important in shaping networks of communication, Magee and Thompson argue that cultural factors such as coethnic ties of trust were crucial in shaping economic behavior in the British Empire. They point out that long-distance trade was a risky thing: costs were high and markets unpredictable, while differences in language, culture, and legal systems all hindered the flow of goods. But professional and family networks helped overcome these risks and obstacles-providing privileged entry into colonial markets and facilitating what Magee and Thompson call an "informational asymmetry" in which the stock of knowledge among London investors was heavily biased in favor of the British settler colonies. ${ }^{88}$ The quality and supply of information, argue Magee and Thompson, shaped decision making, and information flowed more easily along the coethnic networks extended by migration from Britain. For these reasons, they say it is necessary to talk of a "cultural economy." describes the particular and uneven ways in which communication and economic networks were limited by local and affective (including ethnic and racial) factors.

Second, the 1903 delegates also knew that when they articulated the British world as an imagined community, they did so because of their own experience of empire and the feelings it entailed. "I am a graduate of Glasgow University, but I have been in Canada for thirty years," declared Watson. "I know something about the feeling in the Old Country, and I know something about the feeling in the Colony. ${ }^{\prime 00}$ Indeed, the delegates from Canada were particularly anxious to foster a British identity in order to ward off the menacing presence of the United States,

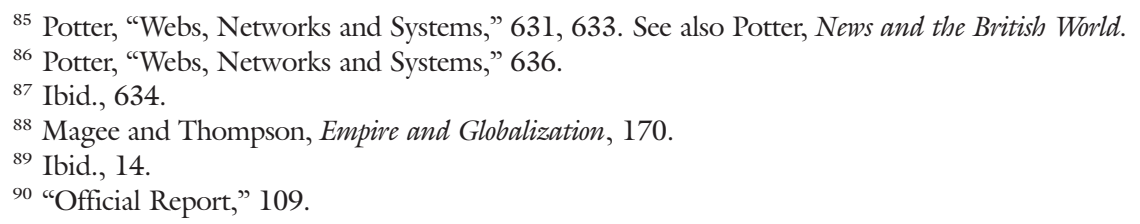


which, according to McGill's principal, Peterson, had already "spoilt Canada of many students." "91 If we are to understand contemporaries' internal worlds of anxiety and hope, fear and memory - with all their implications for cultural, political, and economic life-we need to think about the ways that the relational spaces they inhabited were made by their particular lived experiences of the globalizing world of the late nineteenth century.

We can see this approach underpinning Duncan Bell's work on Victorian political thought. He views the emergence of the idea of Greater Britain in the late nineteenth century as a response to two connected factors: "fear about increasing international competition, both economic and geopolitical, and anxiety about the potentially deleterious consequences of democratic reform. $" 92$ These were both concerns that grew out of the new forms of global connection, including the expansion of industrial capitalism at home and abroad, that were changing the world in the Victorian period. According to Bell, the idea of Greater Britain assuaged these fears by, on the one hand, promising the creation of a federation to rival that of Germany and the United States and, on the other, offering the means by which the diseased and endangered British body politic might be regenerated in the healthy colonies. J. A. Froude, for example, writing in 1870, saw the white colonies as an extension of Britain's land mass: a vast area to which the English could transfer "without ceasing to be Englishmen" and where they could recover the character and the physical vitality through connection with the land that had made Elizabethan England great. ${ }^{93}$ For Bell, then, ideas about a white Greater Britain were responses to fears and anxieties brought home by the new kinds of global connection of the period.

But we might also see the imagined British world as the product of individuals' feelings about their own travels along the routes of empire and their experiences in its various sites and cities. This included feelings of loss and longing attendant upon their own migration or that of their loved ones. For Britons who migrated abroad, the idea that the settler colonies were part of an expansive British community could be a personal consolation that they were not leaving the community to which they had always belonged. But at the same time, it might also be the product of feelings of hope-the chance of social and economic mobility in communities that styled themselves as "better Britains," consciously seeking to maintain England's virtues, while avoiding its mistakes. ${ }^{94}$ Both these constructions of an expansive British community were deeply imbued with notions of racial (and gender) difference, but they were also tied up with the extension abroad of the idea of "home." They were a means by which the positive presence identified as self was projected to those farflung places in which parts of the self, in the shape of friends and relatives, were in very real ways located. Both shaped the cultures of empire and their forms of rule. In this sense, relational British worlds were ways in which real people strove to

91 Ibid., 83.

${ }^{92}$ Duncan Bell, "Empire and International Relations in Victorian Political Thought," Historical Journal 49, no. 1 (March 2006): 297.

${ }^{93}$ Froude, quoted in Peter J. Cain, "Empire and the Languages of Character and Virtue in Later Victorian and Edwardian Britain," Modern Intellectual History 4, no. 2 (August 2007): 259.

${ }^{94}$ James Belich used the term "better Britains" in Paradise Reforged: A History of the New Zealanders, from the 1880s to the Year 2000 (Albany, NZ, 2001). 
make meaning of their feelings about the new forms of global connectivity. ${ }^{95}$ In situations that were often only partially chosen, they were ways of fashioning selves and lives along the uncertain currents of global trade and migration.

Third, when the 1903 conference participants pointed to the "different complexion" of the various settler universities, they were clear that these institutions were shaped not only by their local environments but also by the networks of people, ideas, and practice that connected them to Britain. It was for this reason that Chase could speak of "traditions which will be modified in the light of experience, modified indeed, but never abandoned or destroyed." "W6 When writing about specific locations and the life that took place in them, historians of Britain and its many imperial regions need to consider the ways these local sites and their cultures both shaped the currents of people and goods, ideas and feelings moving in and out of them, and were also shaped by them.

In part, this is the question that has underwritten the new imperial history's examination of the ways in which imperial networks brought the empire home to Britain. As Antoinette Burton has argued, the empire was not "out there" but was a "fundamental and constitutive part of English culture and national identity at home." $"$ B7 But the imbued nature of specific sites is something with which cultural and human geographers, urban historians, and historians of science have all, since the 1980s, also been concerned. This work has seen cities as embedded within the emergent system of global capitalism - shaped by its transnational structures and interdependencies as much as by regional and territorial forces. ${ }^{98}$ Influenced by these shifts, scholars interested in the sociology of knowledge have turned their attention to the geographies of science itself. ${ }^{99}$ They argue that just as urban spaces shape the way people live, so do sites of inquiry condition the investigations carried out in them. Specific places such as the laboratory, as well as regional cultures and environments, were instrumental in forming scientific knowledge, while discreet objects and bodies helped it circulate

95 Tamson Pietsch, "A British Sea: Making Sense of Global Space in the Late Nineteenth Century," Journal of Global History 5, no. 3 (November 2010): 430.

96 "Official Report," 79.

${ }^{97}$ Antoinette Burton, "Introduction: On the Inadequacy and the Indispensability of the Nation," in After the Imperial Turn: Thinking With and Through the Nation, ed. Antoinette Burton (Durham, NC, 2003), 2-3.

${ }^{8}$ Saskia Sassen, The Global City: New York, London, Tokyo (Princeton, 1991); Saskia Sassen, Cities in a World Economy (Thousand Oaks, CA, 1994); Peter J. Taylor, World City Network: A Global Urban Analysis (London, 2004); Jonathan V. Beaverstock, Richard G. Smith, and Peter J. Taylor, "World City Network: A New Metageography?” Annals, Association of American Geographers 90, no. 1 (March 2000), 123-34; Neil Brenner and Roger Keil, "Editor's Introduction: Global City Theory in Retrospect and Prospect," in The Global Cities Reader, ed. Neil Brenner and Roger Keil (London, 2006), 1-16; Peter J. Taylor, Ben Derudder, Pieter Saey, and Frank Witlox, eds., Cities in Globalization: Practices, Policies and Theories (London, 2007), 52-71.

99 Diarmid A. Finnegan, "The Spatial Turn: Geographical Approaches in the History of Science," Journal of the History of Biology 41, no. 2 (Summer 2008), 369-88; David N. Livingstone, "The Spaces of Knowledge: Contributions towards a Historical Geography of Science," Environment and Planning D: Society and Space 13, no. 1 (1995): 5-34; Steven Shapin, "Placing the View from Nowhere: Historical and Sociological Problems in the Location of Science," Transactions of the Institute of British Geographers 23, no. 1 (April 1998): 5-12; Crosbie Smith, Jon Agar, and Gerald Schmidt, eds., Making Space for Science: Territorial Themes in the Shaping of Knowledge (Basingstoke, 1998); Charles Withers, Placing the Enlightenment: Thinking Geographically about the Age of Reason (Chicago, 2007); Peter Meusenburger, David Livingstone, and Heike Jöns, eds., Geographies of Science (Heidelberg, 2010). 
around the globe. ${ }^{100}$ Closely linked to the idea of networks and questions of trust, these perspectives have been taken up by historical geographers who have brought them to bear in their investigations of the British Empire. ${ }^{101}$ Scholars such has Gregory Mann have suggested that "the specifics of particular places [need to] be brought to the fore, not only to ground research empirically but also to disaggregate and cast new light upon colonial and postcolonial circumstances." 102 Turning to the local in this way, argues Phillip Howell, facilitates examination of the simultaneously particular and networked nature of British imperial rule. ${ }^{103}$

These are concerns evident in Saul Dubow's examination of science and knowledge in South Africa. By paying attention to the museums, libraries, and scientific societies established there in the nineteenth and early twentieth centuries, he demonstrates the ways in which the cultivation of "universal" knowledge in these sites was used to buttress a version of South African patriotism "that was sufficiently capacious to reconcile local [English- and Afrikaans-speaking] nationalisms with continued membership of the British Empire." 104 Central to this "South Africanism" was a form of scientific racism that underpinned the technonationalism of the apartheid state. Productive in this way of what we might think of as a "South African" British world, this locally created knowledge was in turn fed back into the channels of imperial science, thereby helping to produce another version of the British world that was defined by race. ${ }^{105}$ How were specific sites - the city, the home, the hospital, the steamship, the dockyards, or indeed the university and the lecture theatre-shaped by, and active in shaping, the relational and relative British world spaces we have been discussing? Historians interested in the sites of imperial rule and in its local culturesboth in the settler world and outside it - might profitably think about the creation and consequences of "British world sites" in this double sense: sites produced by imagined and networked British worlds but also productive of them.

${ }^{100}$ David N. Livingstone, Putting Science in Its Place: Geographies of Scientific Knowledge (Chicago, 2003); Bruno Latour, Science in Action: How to Follow Scientists and Engineers through Society (Milton Keynes, 1987); Sophie Forgan, "Bricks and Bones: Architecture and Science in Victorian Britain," in The Architecture of Science, ed. Peter Galison and Emily Thompson (Cambridge MA, 1999), 181-208; Alison Kraft and Samuel Alberti, "Equal Though Different': Laboratories, Museums and the Institutional Development of Biology in Late-Victorian Northern England," Studies in the History and Philosophy of Biological and Biomedical Sciences 34, no. 2 (June 2003): 203-36.

${ }^{101}$ Adi Ophir and Steven Shapin, "The Place of Knowledge: A Methodological Survey," Science in Context 4, no. 1 (March 1991): 3-21; Charles W. J. Withers, "Reporting, Mapping, Trusting: Making Geographical Knowledge in the Late Seventeenth Century," Isis 90, no. 3 (September 1999): 497-521; Felix Driver, Geography Militant: Cultures of Exploration and Empire (Oxford, 2001); Robin A. Butlin, Geographies of Empire: European Empires and Colonies, c. 1880-1960 (Cambridge, 2009); Phillip Howell, Geographies of Regulation: Policing Prostitution in Nineteenth-Century Britain and the Empire (Cambridge, 2009).

${ }^{102}$ Gregory Mann, "Locating Colonial Histories: Between France and West Africa," American Historical Review 110, no. 2 (April 2005): 410.

${ }^{103}$ Howell, Geographies of Regulation, 21. Work on port cities here is instructive. See, for example, Robert Bickers, "Shanghailanders: Formation and Identity of the British Settler community in Shanghai," Past and Present 159, no. 1 (May 1998): 161-211.

${ }^{104}$ Saul Dubow, A Commonwealth of Knowledge: Science, Sensibility, and White South Africa, 1820-2000 (Oxford, 2006), 162.

105 Saul Dubow, Scientific Racism in Modern South Africa (Cambridge, 1995). 


\section{CONCLUSION}

The comments of the delegates at the 1903 Allied Colonial Universities Conference point to the layered and overlapping set of British worlds they inhabited. Many of the politicians and university professors who gathered in London had personal experience of the networks of global commerce and imperial rule that, at the turn of the twentieth century, were rapidly intensifying. The 1903 delegates' feelings about their experiences of this changing world - feelings of dislocation, anxiety, excitement, and hope-led them to imagine expansive communities defined principally along lines of race. Tracing migratory routes that stretched between Britain and the settler colonies, and exchanging privileges with universities in the United Kingdom, they moved within a world of networks that extended to some places but not others. Across the empire, they found themselves in institutions that, although influenced by British models, were shaped by local concerns, funded by colonial governments, and embedded in particular cultures and communities.

It is as a way of understanding the intersections of these absolute, relative, and relational worlds that the value of the British worlds concept lies. For by paying attention to the complex spaces in which people lived-both those shaped by the routes of long-distance networks and those fashioned by the internal worlds of imagination -this refashioned notion offers one route into understanding the limited and unequal landscapes of the globalizing world. These were landscapes that, in the past as now, certain groups of people were able to navigate more easily than others. The networks of British trade, the ideational tools of an imagined "global Britishness," and the various local enactions of British society were all part of the material and conceptual apparatus by which large numbers of people sought to shape Victorian globalization according to their own individual and collective needs. ${ }^{106}$ 